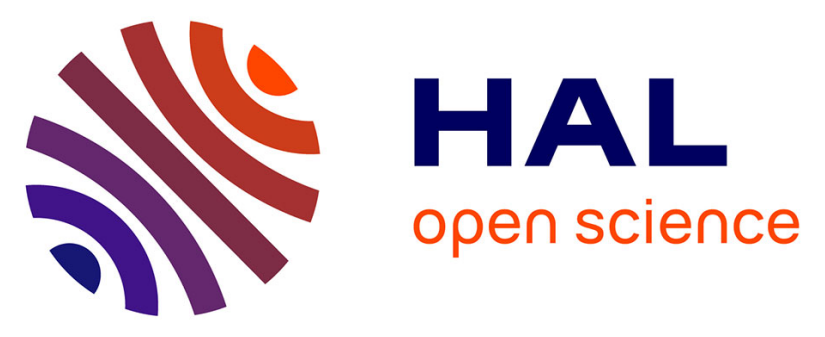

\title{
Impact of post-depositional processes on charcoal fragmentation and archaeobotanical implications: Experimental approach combining charcoal analysis and biomechanics
}

Julia Chrzazvez, Isabelle Théry-Parisot, Gilbert Fiorucci, Jean-Frédéric Terralc, Bernard Thibaut

\section{To cite this version:}

Julia Chrzazvez, Isabelle Théry-Parisot, Gilbert Fiorucci, Jean-Frédéric Terralc, Bernard Thibaut. Impact of post-depositional processes on charcoal fragmentation and archaeobotanical implications: Experimental approach combining charcoal analysis and biomechanics. Journal of Archaeological Science, 2014, 44, pp.30-42. 10.1016/j.jas.2014.01.006 • hal-00951096

\section{HAL Id: hal-00951096}

https://hal-mines-paristech.archives-ouvertes.fr/hal-00951096

Submitted on 25 May 2016

HAL is a multi-disciplinary open access archive for the deposit and dissemination of scientific research documents, whether they are published or not. The documents may come from teaching and research institutions in France or abroad, or from public or private research centers.
L'archive ouverte pluridisciplinaire HAL, est destinée au dépôt et à la diffusion de documents scientifiques de niveau recherche, publiés ou non, émanant des établissements d'enseignement et de recherche français ou étrangers, des laboratoires publics ou privés. 


\title{
Impact of post-depositional processes on charcoal fragmentation and archaeobotanical implications: experimental approach combining charcoal analysis and biomechanics
}

\author{
Julia Chrzazvez $^{\mathrm{a}}$, Isabelle Théry-Parisot ${ }^{\mathrm{a}, *}$, Gilbert Fiorucci $^{\mathrm{b}}$, Jean-Frédéric Terral ${ }^{\mathrm{c}}$, \\ Bernard Thibaut $^{\mathrm{d}}$ \\ ${ }^{a}$ CEPAM-CNRS, UMR 7264, Campus Saint-Jean-d'Angély 3, Université Nice Sophia Antipolis, 24, avenue des Diables Bleus, 06357 Nice Cedex 4, France \\ ${ }^{\mathrm{b}}$ CEMEF, Mines ParisTech, B.P. 207, 06904 Sophia Antipolis Cedex, France

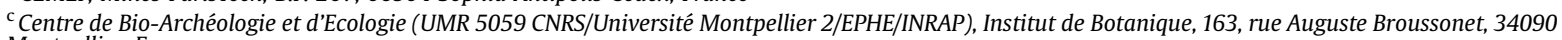 \\ Montpellier, France \\ ${ }^{d}$ CNRS, UMR 5508 LMGC, Place E. Bataillon, cc 048, 34095 Montpellier cedex 5, France
}

\begin{abstract}
Generally speaking, charcoal analysis is based on identifying and counting charcoal fragments in order to calculate the relative variations in taxa frequency. All post-depositional processes are likely to induce fragmentation of the anthracological material, raising the question of the representativeness of taxa. Based on an innovative experimental approach combining both charcoal analysis and biomechanics, this paper explores how the mechanical properties of charcoal can influence the fragmentation and the quantification of species in anthracological assemblages. We carried out standardized laboratory compression tests on 302 samples issued from 10 taxa, charred at three different temperatures, in order to characterize the mechanical properties of common species in temperate and Mediterranean Europe. Our results highlight the differential responses of the tested species in terms of resistance to compression and fragmentation, two processes which do not appear to be correlated. Charcoal is very resistant to pressure (up to $22.5 \mathrm{MPa}$ ). Our results show that significant fragmentation differences exist between taxa. The total number of fragments after compression is largely dependent on the species, regardless of the charring temperature. However, this interspecific variability is more significant for small fragments [1-2 mm], than for larger fragments [2-4 mm] and $>4 \mathrm{~mm}$, with the exception of Quercus, which displays differential reactions to compression. Finally, a multifactorial analysis brings to light the impact of the physical and anatomical characteristics of the different species on charcoal fragmentation.
\end{abstract}

Keywords:

Charcoal analysis

Taphonomy

Mechanical properties

Fragmentation

Experimentation

\section{Introduction}

Charcoal preservation in archaeological sites is variable, even at sites where combustion structures have been identified (ThéryParisot, 2001, 2010c). According to the current state of knowledge, there is no apparent relationship between charcoal preservation and the sedimentary context. Although this observation does not follow a chronological pattern, it is particularly true for Palaeolithic sites (Braadbaart et al., 2009, 2012; Beresford-Jones et al., 2010; Théry-Parisot et al., 2010a), where identifiable, macroscopic-sized charcoal is at times very rare and/or very altered. In such contexts, charcoal is primarily preserved among the mesoscopic and microscopic unidentifiable fraction (Marquer et al., 2010, 2012), raising the question of the impact of post-depositional processes on charcoal preservation. What are the effects of these processes on anthracological assemblages? Do they have a linear effect on charcoal or are some taxa more fragile than others due to their anatomical structure or chemical composition? This naturally brings us to the question of the representativeness of anthracological assemblages for assessing past vegetation and fuel management.

Since the end of the 1990s, some researchers have focused on a methodical approach to the formation process of anthracological assemblages (Théry-Parisot 1998, 2001; 2013; Théry-Parisot et al. 2010a,b), including (i) human practices, (ii) the physical and chemical modifications of wood during combustion, (iii) depositional and post-depositional processes. Human practices are dependent on non-predictable cultural factors specific to each 
group. On the other hand, combustion and post-depositional processes involve physico-chemical and mechanical transformations, which are independent of socio-cultural contexts, and which affect anthracological assemblages in terms of mass reduction and fragmentation. However, most palaeoenvironmental interpretations are partly based on variations in the relative frequency of taxa, calculated by counting the identified fragments in the studied sample. The effects of combustion on charcoal fragmentation have been the subject of numerous studies (cf. infra). Conversely, the effects of post-depositional processes on anthracological assemblages are not so well documented. However, all processes, from trampling to combustion residue, displacement by humans, weathering, water run off transport, bio or cryoturbation phenomena, alternating freeze-thaw cycles or sediment soakingdesiccation, can induce charcoal fragmentation (for a better overview of sites formation processes see for example Goldberg and Macphail, 2013). In this paper, we address the effects of depositional and post-depositional processes and the resulting potential modification of the assemblages.

The aim of this article is to characterize the physical properties of several common temperate and Mediterranean European species in the laboratory, using appropriate measurements on present-day material. By assessing the differential reaction of each species to mechanical post-depositional alteration processes, we can evaluate the palaeoecological representativeness of the anthracological assemblages. This study involves 302 samples issued from 10 taxa, charred at 3 different temperatures and subjected to standardized compression tests. The results should allow us to assess (i) the question of the mechanical properties of charcoal, (ii) the fragmentation level/rate of charcoal from different taxa and (iii) the modalities of this fragmentation. The main objective of this study is to produce data exposing the intrinsic mechanics of the tested species, to evaluate their conservation potential and to appraise the possibility of the under or over-representation of certain species in archaeological contexts.

\section{Research history in charcoal fragmentation}

After some pioneering studies (Salisbury and Jane, 1940; Santa, 1961; Vernet, 1973; Thiébault, 1980), methodological reflections on the representativeness of anthracological assemblages began in the 1980s (Chabal, 1988, 1997, 1990; Badal-Garcia, 1990, 1992). The first approach consisted in analyzing the global fragmentation rate and the size of the fragments of the different taxa in archaeological samples. The analysis of Protohistoric archaeological levels (Le Marduel, Lattes, south of France) yielded fragmentation histograms with a Poisson distribution for all the taxa within the same layer. These studies led to the formulation of the "single fragmentation law" hypothesis for all species (Chabal, 1991, 1997). "A posteriori" analysis included the undifferentiated fragmentation stages: combustion, post-depositional processes, sampling and sieving of the material. At the same time, several studies concentrated on the effects of combustion on anatomy and fragmentation (Rossen and Olson, 1985; Smart and Hoffman, 1988; Scott and Jones 1991; Prior and Gasson, 1993; Loreau, 1994; Vaughan and Nichols 1995; Belcher et al. 2005; Lingens et al. 2005; Braadbaart and Poole, 2008; Théry-Parisot and Chabel, 2010). These works demonstrated "the non-linearity of species behaviour towards fire suggesting that combustion is a taphonomic agent, which randomly affects deposits and whose effect on the assemblage is almost impossible to control" (Théry-Parisot et al., 2010a,b). The impact of post-depositional processes on anthracological assemblages is a less-developed aspect of research. Bio-turbation and transport were mainly studied in the domain of pedo-anthracology (Thinon, 1992; Vaughan and Nichols, 1995; Carcaillet and Talon, 1996;
Blackford, 2000; Nichols et al., 2000; Scott et al., 2000; Scott, 2010; Carcaillet, 2001). Recent work on the impact of pH and diagenesis on the anthracological material has brought to light a structural alteration of charcoal in alkaline environments (Schiegl et al., 1996; Cohen-Ofri et al., 2006; Rebollo et al., 2008; Braadbaart et al., 2009; Ascough et al., 2010, 2011a,b), but also the strong influence of physical processes on the deterioration of the material (Braadbaart et al., 2009). Among these physical processes, mechanical actions, which directly influence the fragmentation of charcoal, play a preponderant role. Freeze/thaw laboratory experiments, coupled with measuring resistance to compression, have shown that wood alteration ante combustion has a strong incidence on the mechanical resistance of charcoal (Théry-Parisot, 1998, 2001). More recently, a study of the mechanical properties of species from the north of India showed that resistance to compression and the dimensions of the ensuing fragments is correlated to charring temperatures (Lancelotti et al., 2010). Mechanical resistance to compression is higher when compression is applied lengthwise to the cross-section and dense wood is more brittle than less compact woods. In temperate regions, abundant data are available concerning the properties of wood used for construction (Ashby, 2005; Forest Products Laboratory, 2010), but nothing indicates that these data can be transposed to charcoal. For this reason we developed an experimental study of the mechanical behaviour of present-day charcoal to evaluate the fragmentation process of the main species identified in temperate European anthracological assemblages.

\section{Materials and methods}

The mechanical tests were carried out in the École des Mines de Paris (ParisTech CEMEF- Sophia-Antipolis, France). The aim of these tests was to measure the mechanical response of charcoal to compression and the fragmentation modalities (number and size of fragments). The experimental procedure is based on previous work by Théry-Parisot $(1998,2001)$

\subsection{Sample preparation}

Sample preparation must take account of both the (i) constraints of the shape of the samples used for the mechanical tests and (ii) the effect of the physico-chemical alteration on the mechanical properties of the material during combustion. It generally involves some form of standardization far removed from the reality of the studied archaeological contexts. The samples have to present two perfectly cut parallel sides with no structural, fissure type alteration.

The production of $2 \mathrm{~cm}$ cubes, with no charring fissures, is one of the restrictions of our protocol.

The tests concerned charred samples from 10 taxa commonly found in archaeological contexts in southern Europe: Acer pseudoplatanus, Betula pubescens, Carpinus betulus, Corylus avellana, Fagus sylvatica, Fraxinus excelsior, Populus tremula, Pinus pinaster, Pinus sylvestris and Quercus pubescens. The dry wood (12\% moisture content) is issued from branches with a $10-15 \mathrm{~cm}$ section.

\subsection{Charring protocol}

In order to limit sample deformation during charring, each cube was wrapped in aluminium foil, placed in a porcelain crucible, covered with sand, and then charred in a muffle furnace. The charring temperature has a direct incidence on the mechanical resistance of charcoal (Hillis, 1984; Fengel and Wegener, 1989; Yildiz et al., 2006; Borrega and Kärenlampi, 2008; Gündüz et al., 2008; Mburu et al., 2008; Korkut et al., 2008; Korkut and 
Hiziroglu, 2009; Kocaefe et al., 2010; Majano-Majano et al., 2012; Poletto et al., 2012). Consequently, the choice of temperature must take into consideration the different stages of the thermal deterioration of the wood (Byrne and Nagle, 1997; Rousset et al., 2006; Braadbaart and Poole, 2008), but must also reflect the probable temperatures of archaeological hearths (Costamagno et al., 2010; Théry-Parisot and Chabal, 2010). The samples were charred at three different temperatures: 400,500 and $750{ }^{\circ} \mathrm{C}$, in porcelain crucibles placed in the hot oven during $30 \mathrm{~min} .302$ of the 400 prepared samples were usable, representing a $25 \%$ loss principally for samples charred at $400^{\circ}$ and $750{ }^{\circ} \mathrm{C}$. On average, 30 samples were tested for each species, with an average of 9.1, 15.6 and 5.5 samples at temperatures of $400{ }^{\circ} \mathrm{C}, 500{ }^{\circ} \mathrm{C}$ and $750{ }^{\circ} \mathrm{C}$ respectively.

\subsection{Physical characterization}

The physical properties of each sample were recorded in order to evaluate their incidence on the fragmentation process. The mass ( $\mathrm{M}$ for dry wood and MC for charcoal), and the dimensions of the cube were measured in 3 directions, first on air-dried wood and then on charcoal. This allowed for the calculation of the volume (V for dry wood and VC for charcoal), the density using the formula $D=M / V($ WD for dry wood, WCD for charcoal), mass loss (M - MC)/ $\mathrm{M}$ (Mloss \%), volume loss (V - VC)/V (Vloss \%) and density loss (WD - WCD)/WD (Dloss \%).

Systematic porosity measurements were taken on the transverse sections of charcoal samples using SEM image analysis. The porosity ratio corresponds to the difference in porosity between the initial and final wood. These measurements were incorporated into the multivariate analysis to include the impact of the porosity of taxa on their mechanical properties and fragmentation. A macro for this measurement was written with image J software (Ducom, 2010).

\subsection{Compression procedure}

A hydraulic traction-compression testing machine, equipped with a $10 \mathrm{kN}$ sensor (Instron 1121), was used for the compression experiments. Pressure was applied parallel to the fibers. The descent speed was fixed at $0.1 \mathrm{~mm} / \mathrm{s}$ during $30 \mathrm{~s}$ from the time of contact with the sample, which was placed on its transversal side.

The pressure applied and the resulting decrease in the height of the sample (displacement of the tray), were recorded during the tests. These values allowed us to plot the stress (MPa)/strain (\%) curves, by dividing the force by the surface of the transversal side of the sample (stress), on one hand, and the displacement by the height of the sample (strain), on the other hand.

Fig. 1 represents a typical test curve. It is comprised of three main parts:

- a gradual rise after the initial contact, which corresponds to setting up the compression;

- a rapid and linear rise of the stress until the peak, which corresponds to the crushing of the whole sample;

- a more or less brutal decrease in stress, possibly with nonnegligible drag strain, corresponding to the destruction of the charcoal structure.

It is noteworthy that compression is never reversible; it is not therefore an elastic phenomenon.

This diagram allows us to calculate several mechanical indicators in phase 2 :

- Maximum stress called crushing strength (CS in MPa);

- Crushing modulus (CM in MPa);

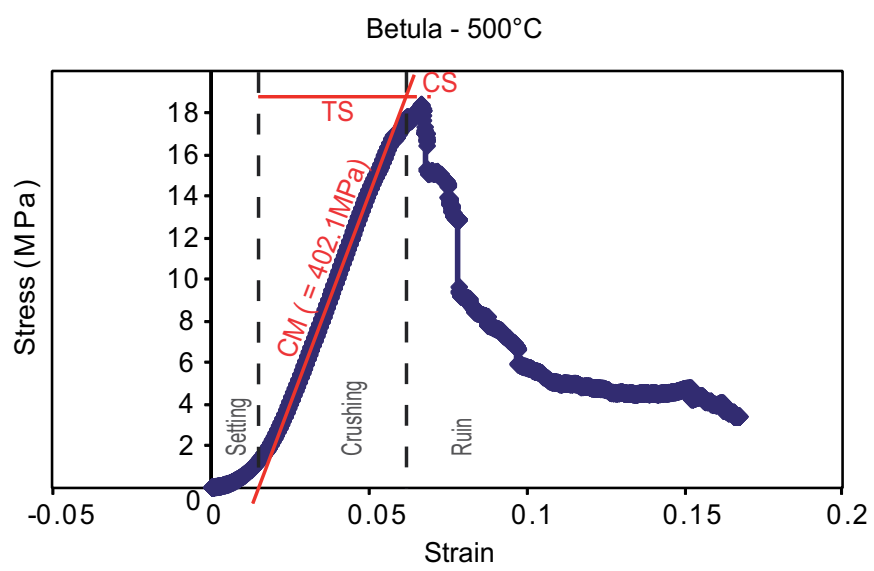

Fig. 1. Typical stress-strain curve of the compression test (comprising the three main phases: setting up the compression test, crushing and destruction of the charcoal structure) and mechanical indicators calculated (CS, CM and TS).

- Theoretical crushing strain $(\mathrm{TS}=\mathrm{CS} / \mathrm{CM})$.

Crushing strength (CS) is directly linked to the maximum force (pressure) that can be applied to a piece of charcoal before complete destruction. If the CS is low, the charcoal is less resistant to pressure.

Theoretical crushing strain (TS) is mainly related to the time required to completely crush the charcoal. If TS is low, the charcoal is more fragile in the compressive test.

Crushing modulus (CM), like any modulus, relates charcoal contraction to the compressive force exerted on it. If $\mathrm{CM}$ is low, the charcoal is less rigid during compression.

As both wood and charcoal are honeycomb-like materials, mechanical properties in grain direction are roughly proportional to their density (Gibson and Ashby, 1999). It is therefore interesting to use "specific" crushing strength, i.e. CS divided by charcoal density: CS/WCD (expressed in $10^{3} \mathrm{~m}^{2} / \mathrm{s}^{2}$ ), as a criterion, independently of density itself.

The applied pressure induces sample fragmentation. The residues of each test were systematically sieved in three different meshes: [1-2 mm], [2-4 $\mathrm{mm}],>4 \mathrm{~mm}$ and the fragments were then counted using image analysis (ImageJ).

\subsection{Statistical methods}

Several univariate to multivariate statistical methods were used to analyze the data and to assess the relation between the mechanical properties and the fragmentation process. The choice of tests depends on the purpose of the analysis and the nature of the available data. Non-parametric tests based on the ranks of the values were chosen when the normality of the distribution was not verified. The Spearman's rank correlation coefficient is a nonparametric measure of statistical dependence between two variables. Regression analysis was used when the dependent variable follows a Normal distribution. The very flexible and extremely powerful oneway analysis of variance (ANOVA), widely used for the analysis of experimental schemes, can simultaneously analyse several scenarios and detect the effects of independent nominal variables on a large number of continuous variables. This test was performed to assess and evaluate the effect of the charring temperature and the taxon on the fragmentation process. The Bonferroni-Dunn test allows for comparisons, controlling the family error rate. It was carried out in order to identify groups of taxon with the same fragmentation process. A multiple correspondence analysis (MCA) was applied to our data set categories to test relationships between variables. 


\section{Results (Table 1)}

\subsection{Physical and mechanical properties}

4.1.1. Mass, volume and density loss.

In our tests, charring induces severe mass, volume and density

If we disregard wood water loss at the beginning of charring (on average $12 \%$ ), on average, mass loss (Mloss) approaches $55 \%$ at $400{ }^{\circ} \mathrm{C}, 60 \%$ at $500{ }^{\circ} \mathrm{C}$ and $70 \%$ at $750{ }^{\circ} \mathrm{C}$. There are no systematic significant differences between the different species.

Volume loss (Vloss) is about $50 \%$ at 400 and $500{ }^{\circ} \mathrm{C}$ and increases to $58 \%$ at $750{ }^{\circ} \mathrm{C}$, which is considerable in comparison to the hygroscopic shrinkage between air-dried wood and oven-dried wood (about 6-8\%). In this case, there are noticeable systematic differences between species, with Quercus pubescens displaying the lowest volume shrinkage and Carpinus betulus the highest.

Density loss (Dloss) increases markedly with temperature (Fig. 2a). It rises from $32 \%$ at $400{ }^{\circ} \mathrm{C}$, to $40 \%$ at $500{ }^{\circ} \mathrm{C}$, and reaches $55 \%$ at $750{ }^{\circ} \mathrm{C}$. Average density loss is $40 \%$, with variations from 33 to $50 \%$ according to the species (Fig. 2b), with Quercus and Carpinus representing the two extremes (Quercus records a much higher density loss than the other species - which tends to slot it into the average - whereas that of Carpinus is much lower).
Charring tends to regulate density differences between species but charcoal density remains globally proportional to the initial wood density (Fig. 2c). The Spearman correlation test indicates a significant positive correlation between the two series of values $\left(\right.$ rho $=0.69 / p$-value $\left.<2.2^{\mathrm{e}}-16\right)$ (Table 2$)$

4.1.2. Crushing strength (CS), crushing modulus (CM) and theoretical crushing strain (TS) (Fig. 3)

\section{The effect of temperature}

The three mechanical indicators evolve markedly with temperature (Table 1). All three decrease when the charring temperature increases, with crushing strength (CS) being more affected than the others. The crushing modulus (CM) decreases slightly between $400{ }^{\circ} \mathrm{C}(424 \mathrm{MPa})$ and $500{ }^{\circ} \mathrm{C}(396 \mathrm{MPa})$, but is almost halved at $750{ }^{\circ} \mathrm{C}(220 \mathrm{MPa})$ (Fig. 3a). Crushing strength (CS) varies on average from $16.9 \mathrm{MPa}$ at $400{ }^{\circ} \mathrm{C}$, to $14.5 \mathrm{MPa}$ at $500{ }^{\circ} \mathrm{C}$ and $6.9 \mathrm{MPa}$ at $750{ }^{\circ} \mathrm{C}$ (Fig. 3b). As for the theoretical crushing strain (TS), it decreases regularly from $4.3 \%$ at $400{ }^{\circ} \mathrm{C}$ to $3.2 \%$ at $750{ }^{\circ} \mathrm{C}$, with a value of $3.8 \%$ at $500{ }^{\circ} \mathrm{C}$ (Fig. 3c).

It appears from these results that charcoal becomes less resistant and more fragile as charring temperatures increase.

Table 1

Average values for mechanical properties and fragmentation of the 10 species and 3 heat treatments. Abbreviations: Nb: number of samples; WD: wood density; WCD: charcoal density; Mloss: mass loss; Vloss: volume loss; Dloss: density loss; $>4 \mathrm{~mm}, 2-4 \mathrm{~mm}, 1-2 \mathrm{~mm}$ : number of fragments in each class size; Total: total number of fragments; CM: crushing modulus; CS: crushing strength; TS: theoretical crushing strain; CS/WCD: specific crushing modulus.

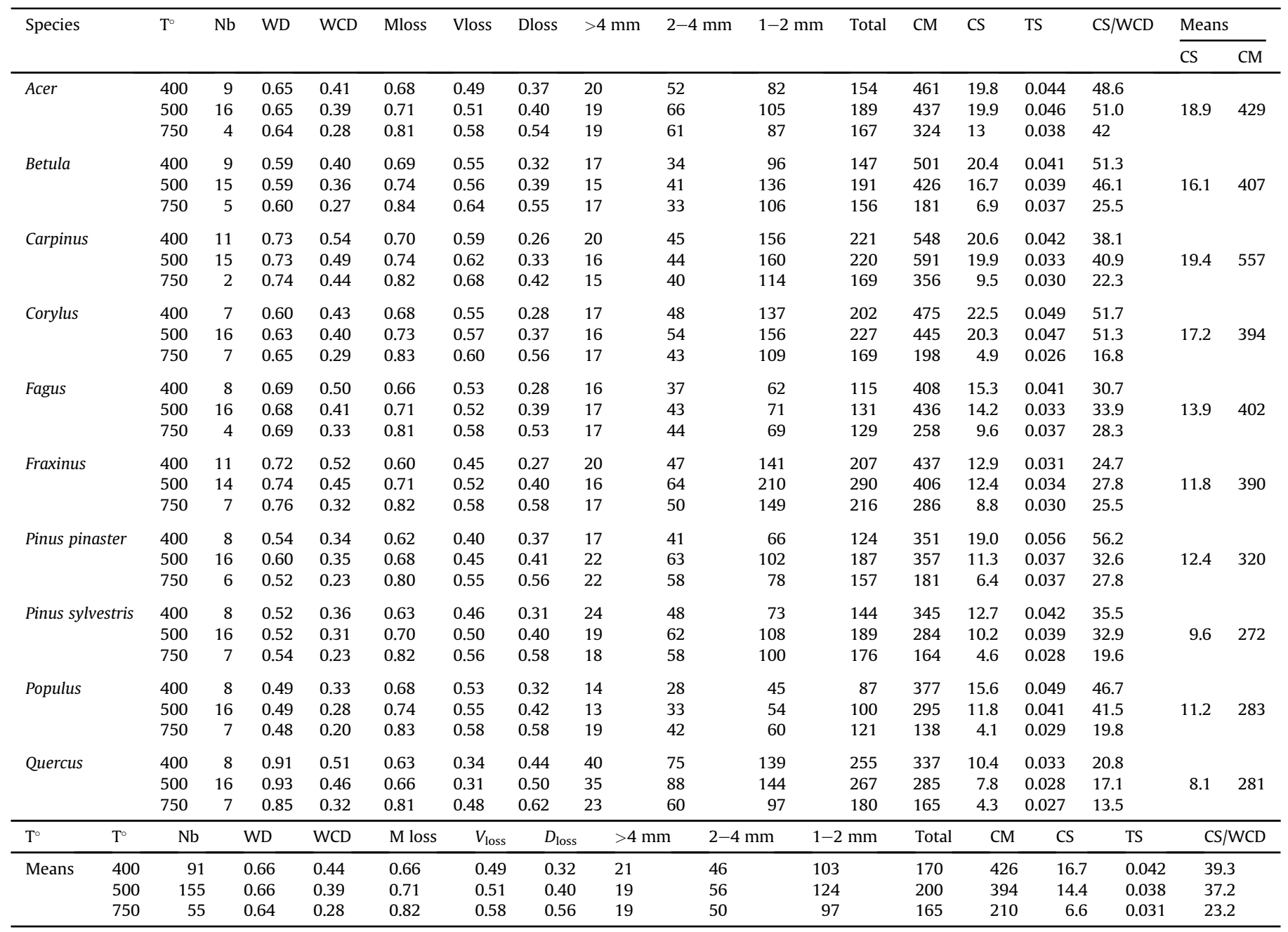



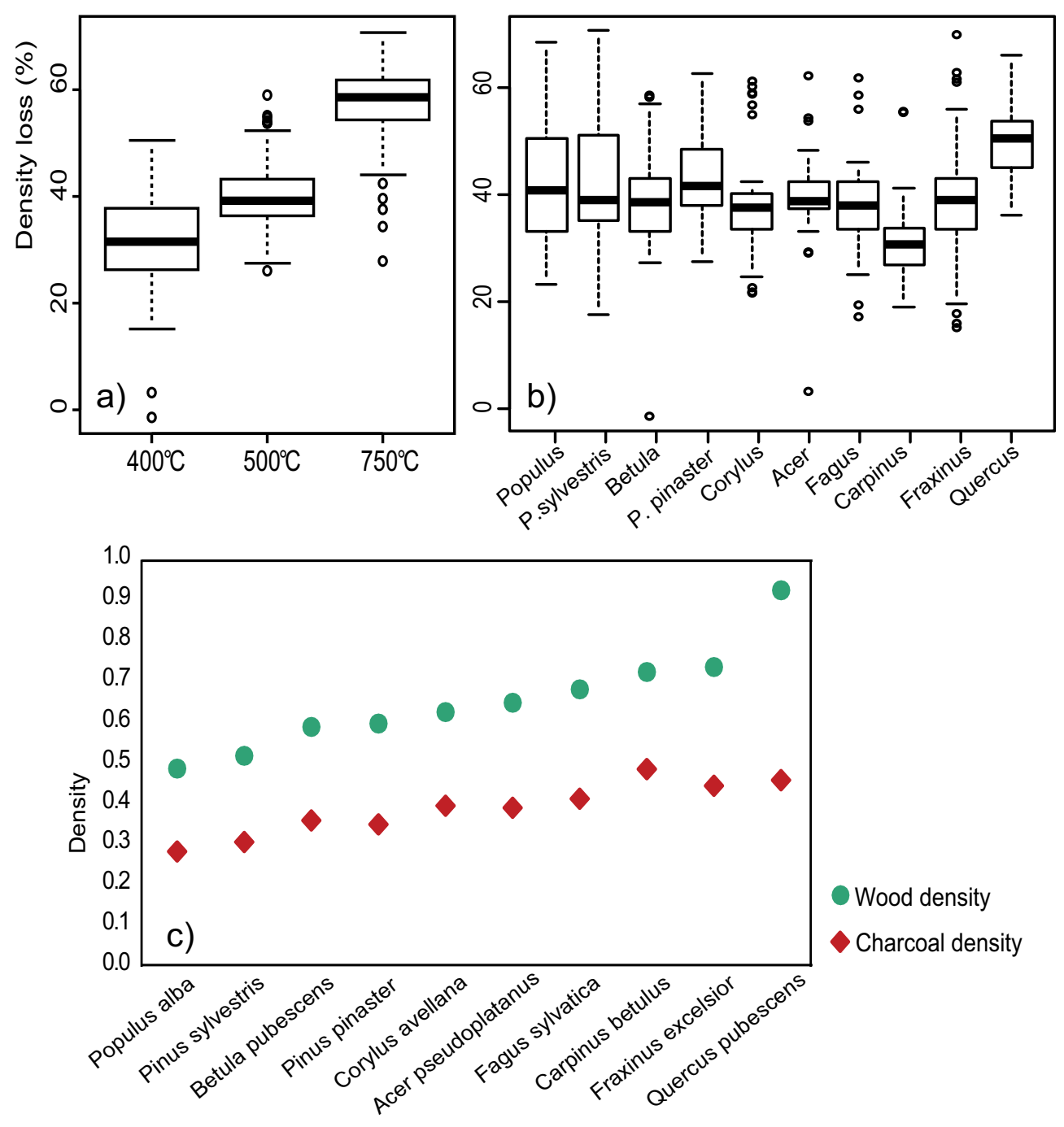

Fig. 2. Mean density loss by charring temperatures (a), by species (b), Mean density of wood and charcoal by species (c).

\section{Species effect}

Due to the fact that a larger and more constant number of specimens were charred at $500{ }^{\circ} \mathrm{C}$, the mean values at this temperature were used to compare species.

The three indicators vary according to the different species (Table 1), which partly explains the substantial standard deviations observed for this temperature. The differences between taxa are noticeable, with CM ranging between $285 \mathrm{MPa}$ for Quercus and $591 \mathrm{MPa}$ for Carpinus, CS between 7.8 MPa for Quercus and 20.3 MPa for Corylus and TS between 2.8\% for Quercus and 4.7\% for Corylus. Quercus is by far the least resistant and most fragile taxon, while Acer, Carpinus and Corylus are the most resistant and the least fragile. The difference is even more accentuated between Quercus and Corylus for the specific crushing strength: respectively 17.1 and 51.3.

- Interaction between the effects of temperature and species

An increase in temperature globally induces a decrease in charcoal resistance (CS), regardless of species (Fig. 3). This decrease is partly due to the reduction in charcoal density, which is most pronounced between 500 and $750{ }^{\circ} \mathrm{C}$.

According to the CIRAD database (Cirad database TROPIX ${ }^{\circledR} 7$, 2011), measurements taken on 243 air-dried wood samples from tree species, with densities ranging from 0.2 to 1.2 , show that resistance to axial compression is proportional to the density of dry wood (WD): CS $=84.7 *$ WD, with a coefficient of regression $R^{2}=0.88$. The CS/WD ratio is called specific resistance (in relation to density) and varies little between species.

It is therefore interesting to compare the specific resistance of charcoal (CS/WCD) to the mean value observed for air-dried wood. On average (Table 1), the ratio between (CS/WCD) and this mean value (84.7) is still 0.48 and 0.44 for $400{ }^{\circ} \mathrm{C}$ and $500{ }^{\circ} \mathrm{C}$ respectively, but it drops to 0.28 at $750{ }^{\circ} \mathrm{C}$.

There are marked differences in temperature between species when the sudden drop in resistance occurs (Fig. 4). Fraxinus, Fagus and Quercus already display low values at $400{ }^{\circ} \mathrm{C}$ and these values do not fall suddenly at $750^{\circ} \mathrm{C}$. Pinus pinaster decreases clearly between 400 and $500{ }^{\circ} \mathrm{C}$ but not so much between 500 and $750{ }^{\circ} \mathrm{C}$. All the other species present a strong decrease in resistance between 500 and $750{ }^{\circ} \mathrm{C}$.

\subsection{Fragmentation}

\subsubsection{Global fragmentation process, all class sizes combined}

After the compression tests, the samples produced on average, 170 fragments at $400{ }^{\circ} \mathrm{C}, 200$ fragments at $500{ }^{\circ} \mathrm{C}$ and 165 fragments at $750{ }^{\circ} \mathrm{C}$ (Fig. 5a). The relationship between temperature 
Table 2

Table of correlations between variables (Spearman test).

\begin{tabular}{llccl}
\hline Pairs of variables & & $\begin{array}{l}\text { Coef. correlation } \\
\text { (Rhô) }\end{array}$ & $p$-Value & $\begin{array}{l}\text { Coef. } \\
\text { determination }\end{array}$ \\
\hline WD & WCD & 0.708 & $<0.0001$ & 0.501 \\
Total Nb fragt & WD & 0.517 & $<0.0001$ & 0.267 \\
Total Nb fragt & WCD & 0.433 & $<0.0001$ & 0.188 \\
Total Nb fragt & CM & 0.170 & 0.003 & 0.029 \\
Total Nb fragt & CS & 0.070 & 0.225 & 0.005 \\
Total Nb fragt & CS/WCD & -0.090 & 0.120 & 0.008 \\
Total Nb fragt & Dloss & 0.019 & 0.739 & 0.000 \\
Nb fragt [1-2 mm] & WD & 0.496 & $<0.0001$ & 0.246 \\
Nb fragt [1-2 mm] & WCD & 0.464 & $<0.0001$ & 0.215 \\
CM & WCD & 0.516 & $<0.0001$ & 0.266 \\
CM & Dloss & -0.587 & $<0.0001$ & 0.344 \\
CS & WCD & 0.404 & $<0.0001$ & 0.163 \\
CS & Dloss & -0.671 & $<0.0001$ & 0.451 \\
\hline
\end{tabular}

and the number of fragments is therefore not consistent during our tests. The total number of fragments for each species presents marked variability, ranging from 34 fragments for Populus to 400 for Fraxinus, with, on average, 101 fragments for Populus and 246 for Quercus pubescens.

The differences between species are significant, as shown by the results of the ANOVA (Table 3), which make it possible to classify the effects of temperature and species. Both factors combined account for $61.5 \%$ of the total variability but the $F$ - value and the sum of the squares for the SPECIES factor are more significant, explaining $49.7 \%\left(R^{2}\right)$ of the variation of the model. The histogram (Fig. 6) summarizing the total number of fragments produced by compression, according to species and temperature, clearly shows the preponderant role of the taxon on fragmentation. Apart from some rare exceptions $\left(500^{\circ} \mathrm{C} /\right.$ Fraxinus), the observed variability is much more significant between the different species than between temperatures.

A bilateral paired-comparison test brings to light four partly overlapping groups of taxa. Populus on one hand, and Quercus and Fraxinus on the other hand, display contrasting responses, which differ from those of most species. On average, Populus is not very fragmented whereas Quercus and Fraxinus are much more fragmented. The other species are clustered around two median groups. Fagus is similar to Populus, followed by a group made up of P. pinaster, Acer and Betula. P. sylvestris, Corylus and Carpinus tend to display slightly greater fragmentation and $P$. sylvestris has median fragmentation (Table 4).

\subsubsection{Mechanical properties versus fragmentation}

Series of Spearman tests show that, on the whole, there is virtually no link between mechanical properties and the fragmentation process (Table 2). Mass loss, crushing strength and specific crushing
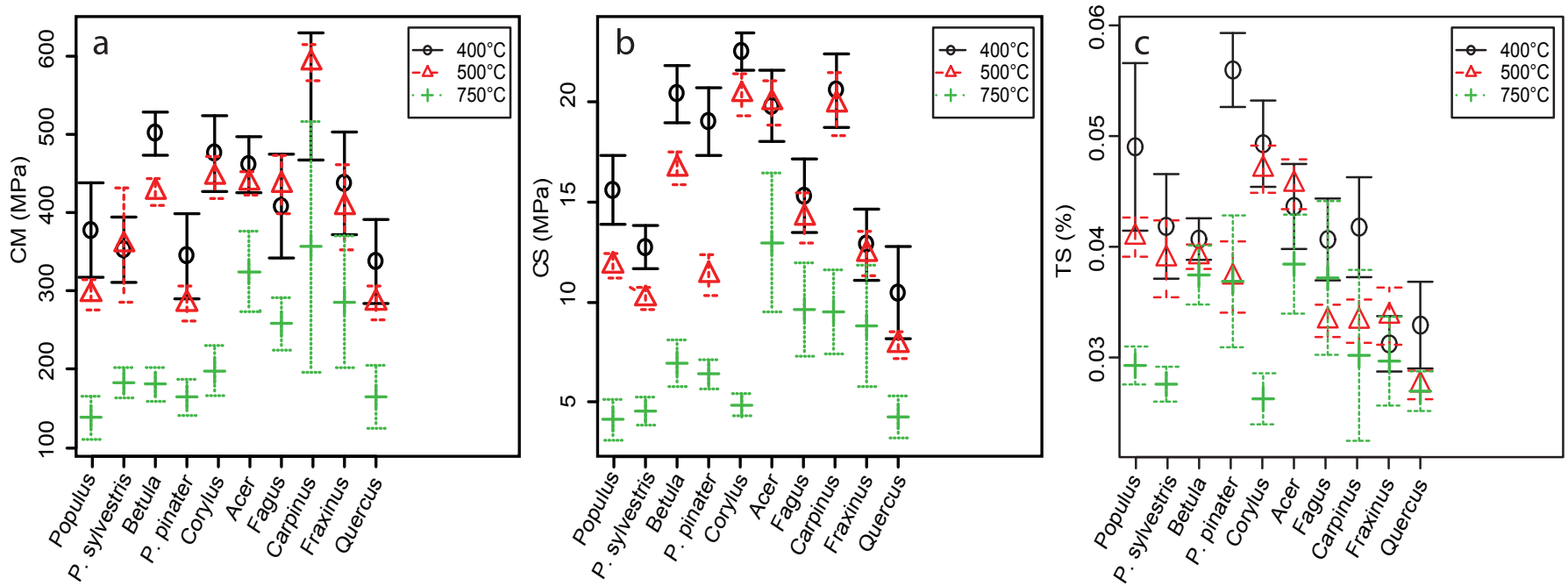

Fig. 3. Interaction between temperatures and species on the mechanical properties: crushing modulus CM (a); crushing strength CS (b); theoretical crushing strain TS (c).
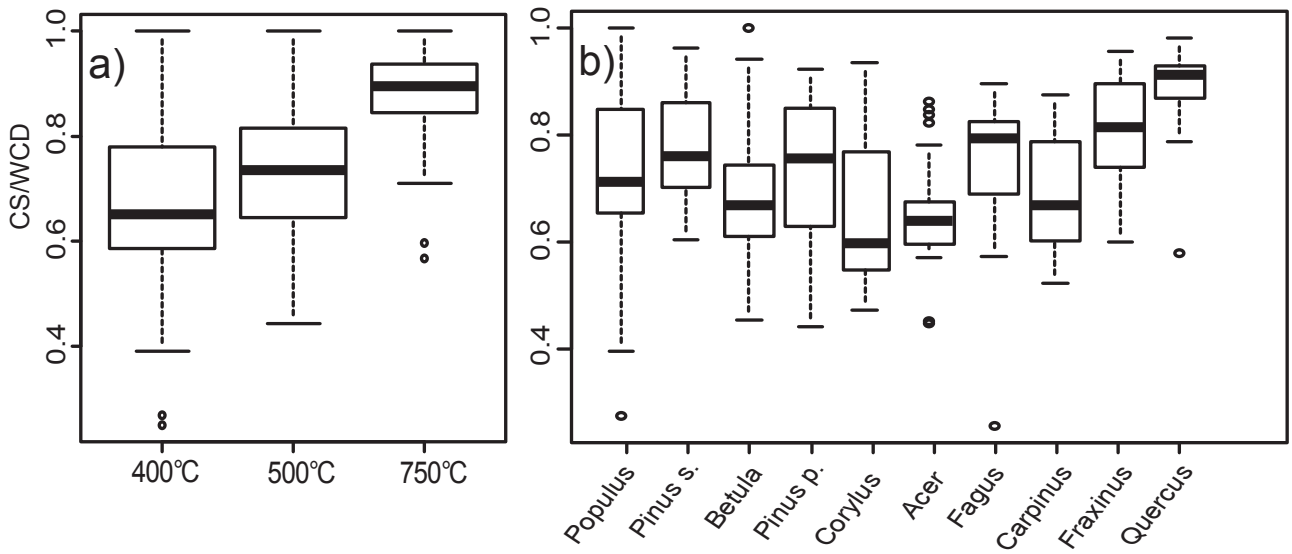

Fig. 4. Specific rupture strength (CS/WCD) by: temperature (a) and species (b). 

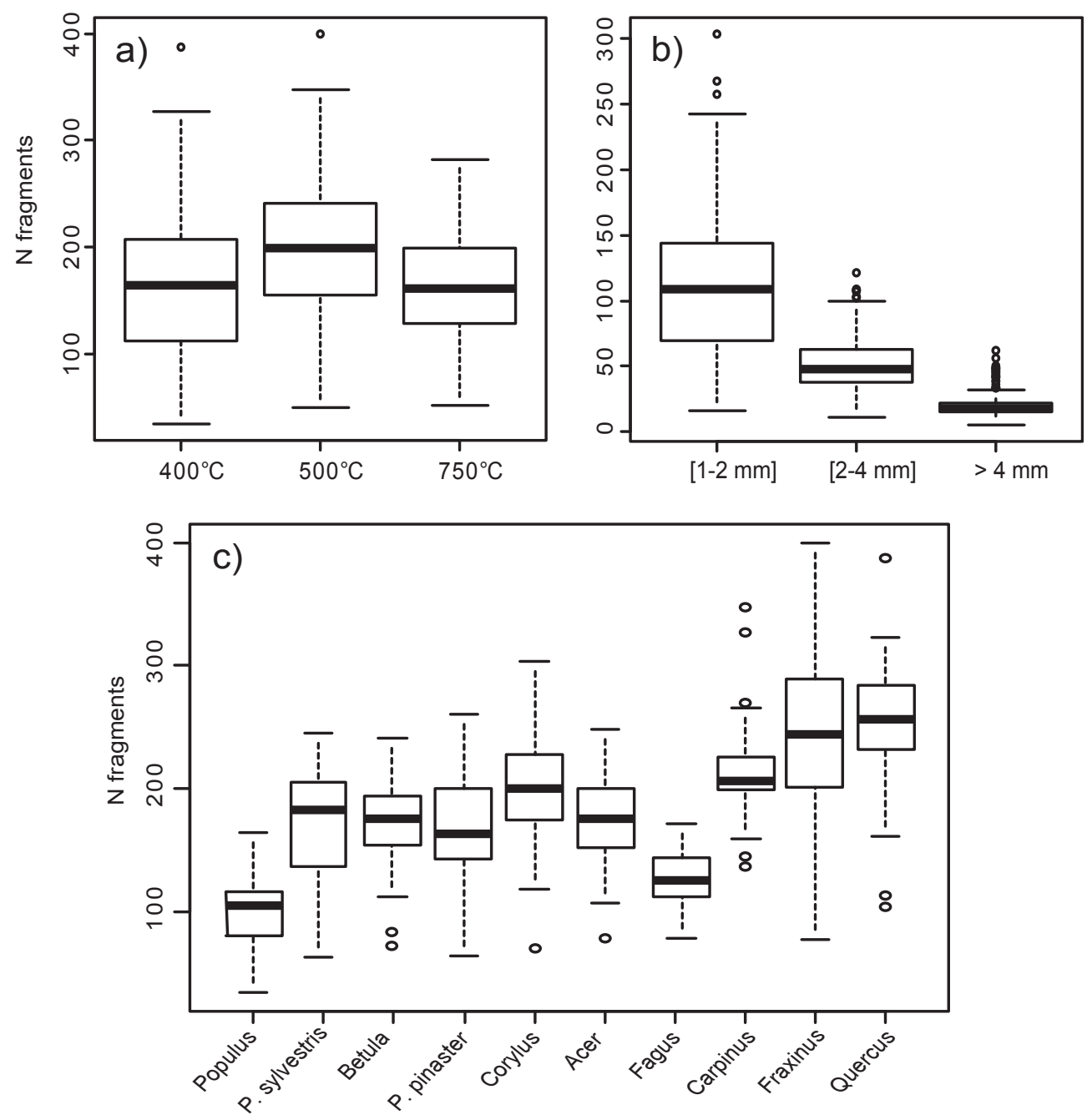

Fig. 5. Box \& Whiskers plot for the total number of fragments: by charring temperature (a), by class sizes (b), by species (c).

strength are not correlated with the total number of fragments produced. The crushing modulus is very slightly correlated with the total number of fragments: the $p$-value is significant $(0.0076)$, but the determination coefficient is low $($ rho $=0.15)$. Scatter graph (Fig. 7 ) explicitly shows that there is no relation between crushing strength (which is a good expression of the brittleness of charcoal) and the number of fragments produced by compression tests. In other words, mechanical properties and fragmentation are strongly dependent on the species, but there is no correlation between the two factors themselves. Each species is more or less resistant to compression but once the fragmentation process has begun, it affects each species independently of the pressure applied.

\subsubsection{Fragmentation modalities by class size [1-2 $\mathrm{mm}],[2-4 \mathrm{~mm}$, $>4 \mathrm{~mm}$}

The first observation concerns the disparity in fragment distribution between the different class sizes. All species combined, the average number of fragments by class size is 111 in the smallest class size $[1-2 \mathrm{~mm}], 51$ in the second [2-4 mm], and only 19 fragments larger than $4 \mathrm{~mm}$ (Fig. 5b).

According to the species, the number of fragments varies from 16 to 304 in the class [ $1-2 \mathrm{~mm}$ ], from 11 to 121 in the class [2$4 \mathrm{~mm}$ ] and from 5 to 62 in the class $>4 \mathrm{~mm}$ (Fig. $5 \mathrm{c}$ ). The variance of the three series is thus quite marked and the coefficient of variation is around $40 \%$ for the three class sizes.
Fragmentation variability by species is very significant in the class [1-2 mm] with substantial tiering of the dispersion boxes (Fig. 8a). Populus is the least fragmented species with a minimum of 16 fragments and Fraxinus is the most fragmented species with a maximum of 304 fragments. The bilateral paired-comparison test (Bonferroni-Dunn procedure, Table 4) distinguishes four significantly different groups.

The upper and lower extremes are respectively made up of an isolated species, Populus, and a group made up of Corylus, Quercus, Carpinus, Fraxinus, which generally yields more fragments. Fagus and P. pinaster are similar to Populus, whereas Acer, $P$. sylvestris and Betula display intermediate fragmentation, between the species with high and low fragmentation. Variability is less marked in the intermediate class [2-4 $\mathrm{mm}$ ], where divergence between the species is slightly reduced and only two species deviate: Populus generally produces less fragments (mean $=33$ ) and Quercus (mean $=78$ ) produces on average a lot more fragments. As for the other species, Betula, Fagus, Carpinus and Corylus present a low fragmentation tendency whereas Fraxinus, P. Sylvestris, P. pinaster and Acer display a high tendency (Fig. 8b).

Lastly, in the $>4 \mathrm{~mm}$ class, the dispersion boxes have a more or less constant distribution, apart from Quercus, which is quite detached from the other species (Bonferroni-Dunn-test). Variability is generally much less significant here (Fig. 8c). 
Table 3

Effect of species and temperature on fragmentation (ANOVA one-way variance analysis and PLSD Fisher test).

\begin{tabular}{lcccc}
\hline Variable & DDL & Sum of the squares & $F$ value & $\operatorname{Pr}>F$ \\
\hline Species & 9 & 671386.8 & 40.762 & $<0.0001$ \\
Temperature & 2 & 45851.4 & 25.054 & $<0.0001$ \\
Species * temperatures & 18 & 68889.6 & 2.091 & 0.006 \\
\hline
\end{tabular}

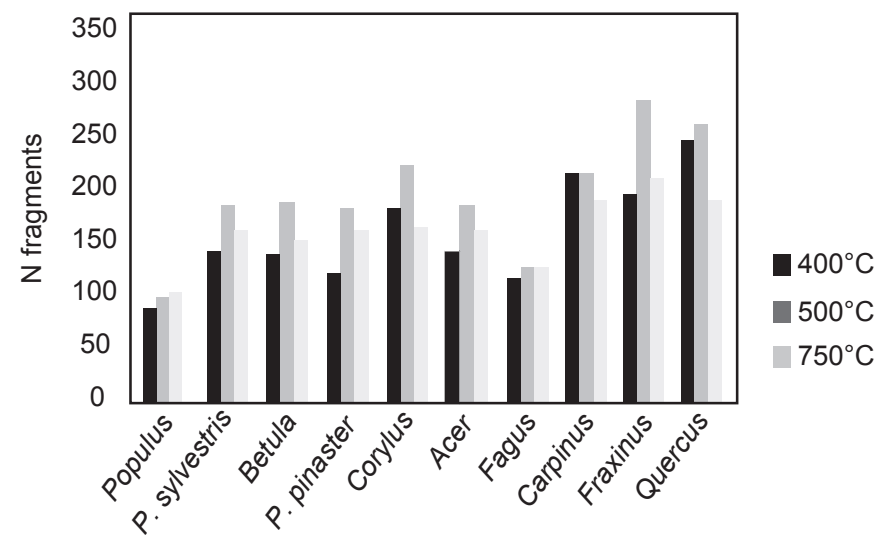

Fig. 6.

Differences between taxa are thus very slight in the $>4 \mathrm{~mm}$ size and relatively minor in the $[2-4 \mathrm{~mm}]$ class. They are most marked in the $[1-2 \mathrm{~mm}]$ class.

\subsection{Multivariate analysis}

The multiple correspondence analysis (MCA) conducted on all the specimens charred at $500{ }^{\circ} \mathrm{C}$ allows us to discuss the relationships between our results and the main physical and anatomical characteristics of the studied species. Only the variables with a strong impact on the analysis have been retained (defined by two or three modalities: high/medium/low). For example, fiber thickness was initially tested and then removed. Moreover, the species themselves are integrated as supplementary variables and are not used for the calculation of the ACM (Fig. 9).

On axis 1 , accounting for $62.21 \%$ of the total variance, the "large vessels", "very large and long rays" and "high porosity" modalities are closely linked. These modalities are secondarily associated with the absence of spiral thickenings and are related to a low crushing strength (CS) and a high number of fragments $>4 \mathrm{~mm}$. On axis 2 , in the upper right part of the graphic, in relation to the active variables on axis 1 , "high density" is strongly correlated with the high values of the total number of fragments and the high number of fragments $>1 \mathrm{~mm}$.
In the upper left part, the high crushing strength is strongly correlated to the presence of spiral thickenings and, secondarily, to the "small aggregate vessels" modality.

Lastly, in the lower part of the graphic, the "low density" (WCD) and "small isolated vessels or homoxylous wood" are linked to the low total number of fragments.

Wood with a marked porous zone, with large vessels, such as Quercus and Fraxinus, and with long radial file vessels (Carpinus and Corylus) are the most fragmented. Homogeneous wood (small isolated diffuse vessels or homoxylous) such as Populus, Acer, Betula or $P$. pinaster, $P$. sylvestris are those that produce fewer fragments. Corylus, Carpinus and Acer present a higher crushing strength than the other taxa. This characteristic seems to be linked to the presence of spiral thickenings. Conversely, the weak value of crushing strength is either linked to the porosity of the charcoal (case of Fraxinus and Quercus), or to its low density, as is the case for Populus, $P$. sylvestris and $P$. pinaster. In all cases, wood with a low density presents a low value for crushing strength. On the other hand, dense wood alternatively yields either very high or very low values.

\subsection{Results synthesis}

Table 3 summarizes correlation coefficients and brings to light the differential responses of the tested species as regards resistance to compression and fragmentation. These two processes are clearly not related. We have observed that:

- Temperature increase generally induces a decrease in the resistance of the charcoal, whatever the species (Fig. 3). This is similar to the results of tests carried out at low temperatures on industrial wood (Gündüz et al., 2008; Korkut et al., 2008; Korkut and Hiziroglu, 2009; Kocaefe et al., 2010; Majano-Majano et al., 2012). Crushing strength loss is particularly noticeable above $500{ }^{\circ} \mathrm{C}$.

- Density loss is correlated to the charring temperature but is also related to the species. However, charring tends to attenuate the differences in density between species (Fig. 2).

- Density loss induces crushing strength loss and accounts for the main mechanical properties of charcoal.

- All temperatures combined, charcoal resistance is also linked to the species. The mechanical properties of the species are modified at distinctive thermal thresholds (Fig. 3).

- Resistance to pressure is dependent on the species but fragmentation intensity is not correlated to the resistance of the material itself. The least resistant species are not those subject to the most fragmentation (Fig. 7).

- The relationship between the number of fragments produced by compression and temperature is not constant (Fig. 5a).

- The total number of fragments after compression depends mainly on the species, regardless of temperature (Table 3 and

Table 4

Groups of species vs. fragmentation (Dunn-Bonferroni Test).

\begin{tabular}{|c|c|c|c|c|c|c|c|c|c|c|c|c|c|c|c|c|c|c|c|c|}
\hline \multicolumn{6}{|l|}{ Total } & \multicolumn{5}{|l|}{ [1-2 mm] } & \multicolumn{6}{|l|}{$[2-4 \mathrm{~mm}]$} & \multicolumn{4}{|l|}{$>4 \mathrm{~mm}$} \\
\hline Taxon & \multicolumn{5}{|c|}{ Groups } & Taxon & \multicolumn{4}{|c|}{ Groups } & Taxon & \multicolumn{5}{|c|}{ Groups } & Taxon & \multicolumn{3}{|c|}{ Groups } \\
\hline Populus & A & & & & & Populus & A & & & & Populus & A & & & & & Populus & A & & \\
\hline Fagus & A & B & & & & Fagus & A & B & & & Betula & A & B & & & & Betula & A & & \\
\hline P. pinaster & & B & C & & & P. sylv. & A & B & $\mathrm{C}$ & & Fagus & A & B & C & & & Corylus & A & B & \\
\hline Betula & & B & C & $\mathrm{D}$ & & Acer & & B & C & & Carpinus & A & B & C & $\mathrm{D}$ & & Fagus & A & B & \\
\hline Acer & & & C & D & & P. pinaster & & B & $\mathrm{C}$ & & Corylus & & B & C & $\mathrm{D}$ & & Carpinus & A & B & \\
\hline P. sylv. & & & C & D & & Betula & & & C & $\mathrm{D}$ & Fraxinus & & & C & $\mathrm{D}$ & & Fraxinus & A & B & \\
\hline Corylus & & & C & D & $\mathrm{E}$ & Corylus & & & & D & P. pinaster & & & C & $\mathrm{D}$ & & P. sylv. & A & B & \\
\hline Carpinus & & & & $\mathrm{D}$ & E & Quercus & & & & $\mathrm{D}$ & P. sylv. & & & C & $\mathrm{D}$ & & Acer & A & B & \\
\hline Fraxinus & & & & & E & Carpinus & & & & $\mathrm{D}$ & Acer & & & & $\mathrm{D}$ & E & P. pinaster & & B & \\
\hline Quercus & & & & & E & Fraxinus & & & & $\mathrm{D}$ & Quercus & & & & & E & Quercus & & & C \\
\hline
\end{tabular}




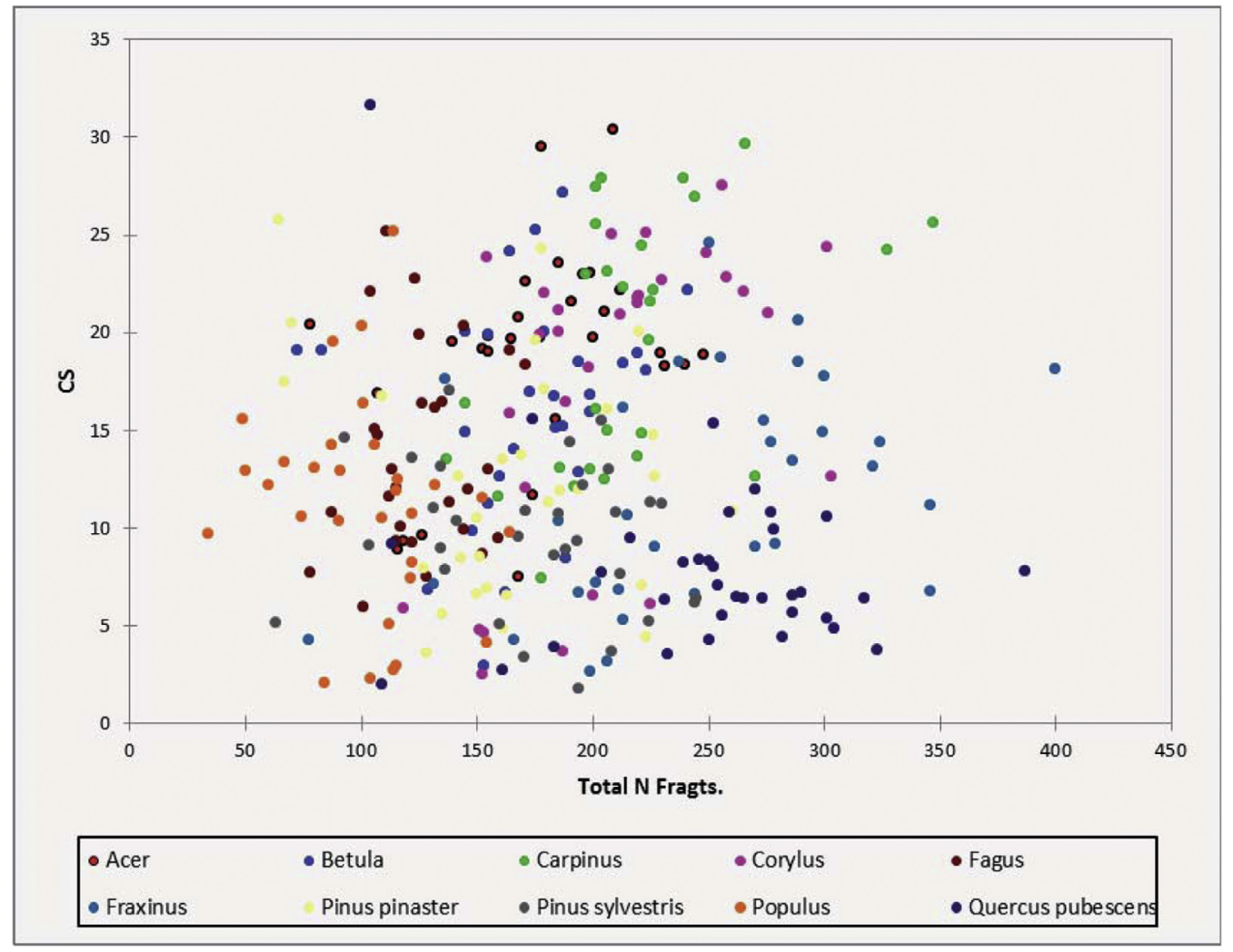

Fig. 7. Effect of the Specific rupture strength on the number of fragments.

Fig. 6). Populus is not prone to much fragmentation whereas Quercus and Fraxinus produce a lot of fragments. Between these two extremes, Fagus, P. pinaster, Acer and Betula display little fragmentation, whereas Corylus and Carpinus tend to be highly fragmented. $P$. sylvestris shows an intermediate response to fragmentation (Table 4 and Fig. 5c).

- However, interspecific variability is significant for the small fragments [1-2 $\mathrm{mm}$ ], but less so for larger fragments [2-4 mm]. In the largest class size ( $>4 \mathrm{~mm}$ ), only Quercus is different from the other taxa, producing a lot more fragments (Fig. 8).

- Wood with a marked porous zone, with large vessels, and with long radial file vessels (Carpinus and Corylus) produces the most fragments. Homogeneous wood (small isolated diffuse vessels or homoxylates) such as Populus, Acer, Betula or P. pinaster, P. sylvestris are those that produce the least fragments (Fig. 9).

- The presence of spiral thickenings (Corylus, Carpinus and Acer) is linked to a higher crushing strength. The low value of crushing strength is either linked to the porosity of the charcoal (Fraxinus and Quercus), or to its low density (Populus, P. sylvestris and $P$. pinaster). In all cases, wood with a low density presents a low value for crushing strength. On the other hand, dense wood alternatively yields either very high or very low values (Fig. 9).

\section{Interpretation}

\subsection{Focus on factors impacting fragmentation}

Density

The density of dry wood seems to have an impact on fragmentation: charcoal from dense wood is very fragmented while low to medium density wood charcoal presents low to medium fragmentation. Despite a low coefficient of determination (0.267), there is a significant positive correlation ( $\mathrm{Rhô}=0.517$ ) between "wood density" (and therefore charcoal density) and the "total number of fragments". As the majority of the fragments are in the [1-2 mm] fraction, density is also logically correlated with the number of small fragments, as shown by the MCA analysis: the denser the wood, the higher the number of small fragments.

\section{- Wood porosity vs. homogeneity}

Fragmentation intensity is related to charcoal porosity. Cellular organization seems to be strongly linked to the fragmentation processes. Marked porous zones with large vessels or radial pore files are prone to fragmentation. Conversely, more homogeneous porous wood (with small isolated diffuse vessels or homoxylates) such as Populus, Acer, Betula or P. pinaster, P. sylvestris tends to be less fragmented.

Length and width of the rays

The production of large fragments, as for Quercus, is also linked to the presence of a significant porous zone. But Quercus differs from the other species by the presence of multiseriate rays, which create fragile zones after combustion and account for the specific fragmentation mode of this species. For the other species, the rays, whether multiseriate or uniseriate, play a secondary role in both fragmentation and the mechanical properties (cf. central position and weak contribution in the construction of the MCA graphic).

\subsection{Factors affecting crushing strength}

In all cases, charcoal with a low density presents a low value for crushing strength, but high density charcoal alternatively yields 

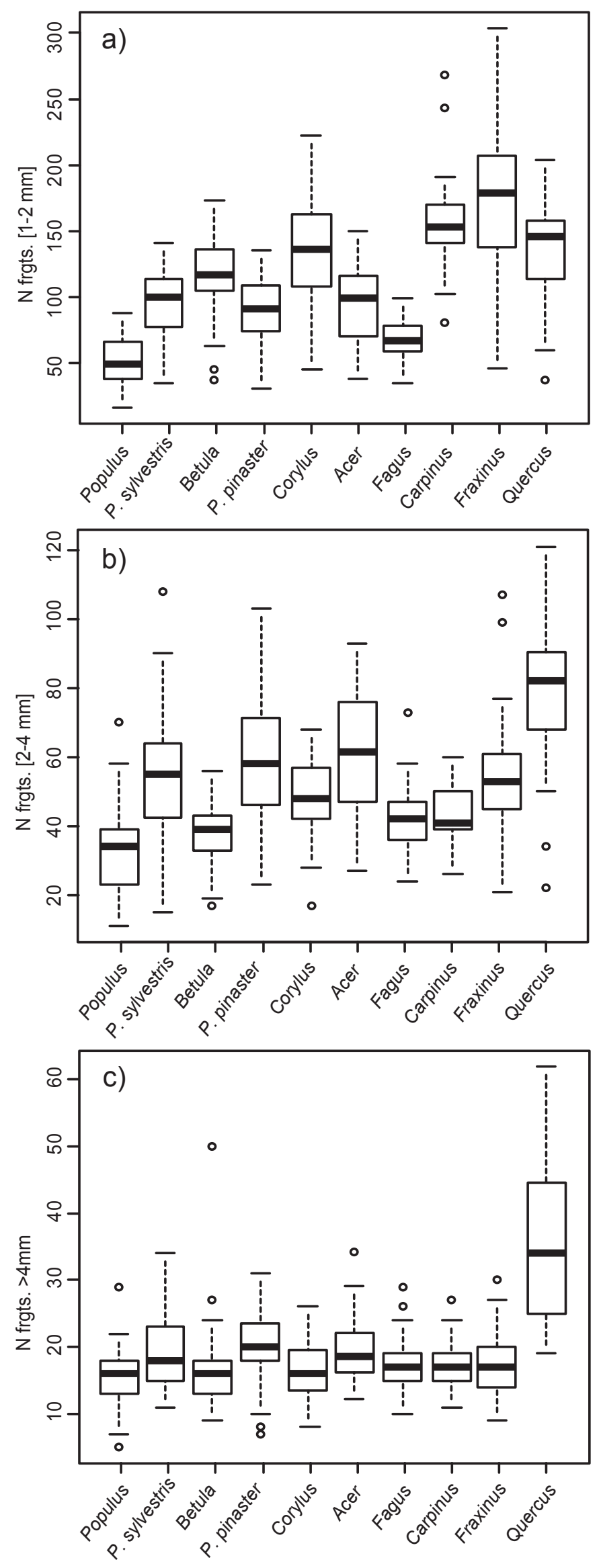

very high or very low values. The relationship between charcoal density and crushing strength is thus not clear.

Corylus, Carpinus and Acer present a higher crushing strength than the other taxa. This characteristic is linked to the presence of spiral thickenings, which are preserved after charring. Conversely, the weak value of crushing strength is either linked to the porosity of the charcoal, in the case of Fraxinus and Quercus, or to its low density, as is the case for Populus, P. sylvestris and P. pinaster.

For dry wood, crushing strength is more or less proportional to wood density. Although Quercus is the wood with the highest density, its charcoal has the lowest crushing strength. This is due to the fact that charring induces the highest density loss for this species, perhaps because of its chemical composition. In addition, Quercus displays two orthogonal arrays of weak zones: an initial porous zone in a tangential direction and very large rays in the radial direction. This should be conducive to the initiation of a large number of cracks at rather low stress levels.

On the other hand, Corylus, Carpinus and Acer present a higher crushing strength than the other taxa, although the density of these species is no higher than that of Fraxinus, for example. They are more homogeneous woods with less distinct weak zones prone to fractures. Furthermore, the presence of spiral thickenings in the fibers, which are preserved after charring, appears to reinforce the structure of these charred woods.

Populus is characterized by a very homogeneous structure, but with a much lower density than the former species.

The low resistance of Fraxinus and Fagus charcoal, in spite of the rather high density of these woods, can also be explained by the presence of weak zones: tangential (initial porous zone) for Fraxinus and radial (large rays) for Fagus.

\section{Discussion: from experimentation to the archaeological context}

This study shows that the anatomical structure of the different tested wood taxa has a significant impact on the mechanical properties of charcoal. Charring produces less heterogeneous material than the different initial woods, but it does not erase the differences in density, organization and cellular composition, etc.

Thermal response, resistance to pressure, fragmentation and its modalities are largely dependent on the anatomical features and thus, on the physical characteristics of wood. Some of the noted differences are significant from an archaeological viewpoint. The alteration of the mechanical properties follows a differential thermal pattern depending on the species, which can cause differences in taxa fragmentation in the same hearth or among scattered charcoals. The formation temperature of charcoal also influences the fragmentation of the material (Théry-Parisot, 2013). Yet, the temperatures are highly fluctuant in a same combustion structure. It is therefore very difficult to archaeologically assess the question of the weakness of charcoal in relation to charring temperatures.

Fragmentation differences are mainly visible outside the [ $>4 \mathrm{~mm}$ ] class size. These first results tend to show that anthracoanalysis limited to charcoal over $4 \mathrm{~mm}$ would induce less risk of under or over-representation of the different taxa, with the exception of Quercus, which is over-represented in this class size.

We also noted variations in crushing strength values from one species to another. This signifies that the rupture of the material is not initiated at the same pressure levels. Thus, from an archaeological perspective, in the same burial conditions, taxa will not necessarily demonstrate the same resistance capacity, which could

Fig. 8. Box \& Whiskers plot for the number of fragments by species in the three class sizes: $1-2 \mathrm{~mm}(\mathrm{a}) ; 2-4 \mathrm{~mm}$ (b); $>4 \mathrm{~mm}$ (c). 


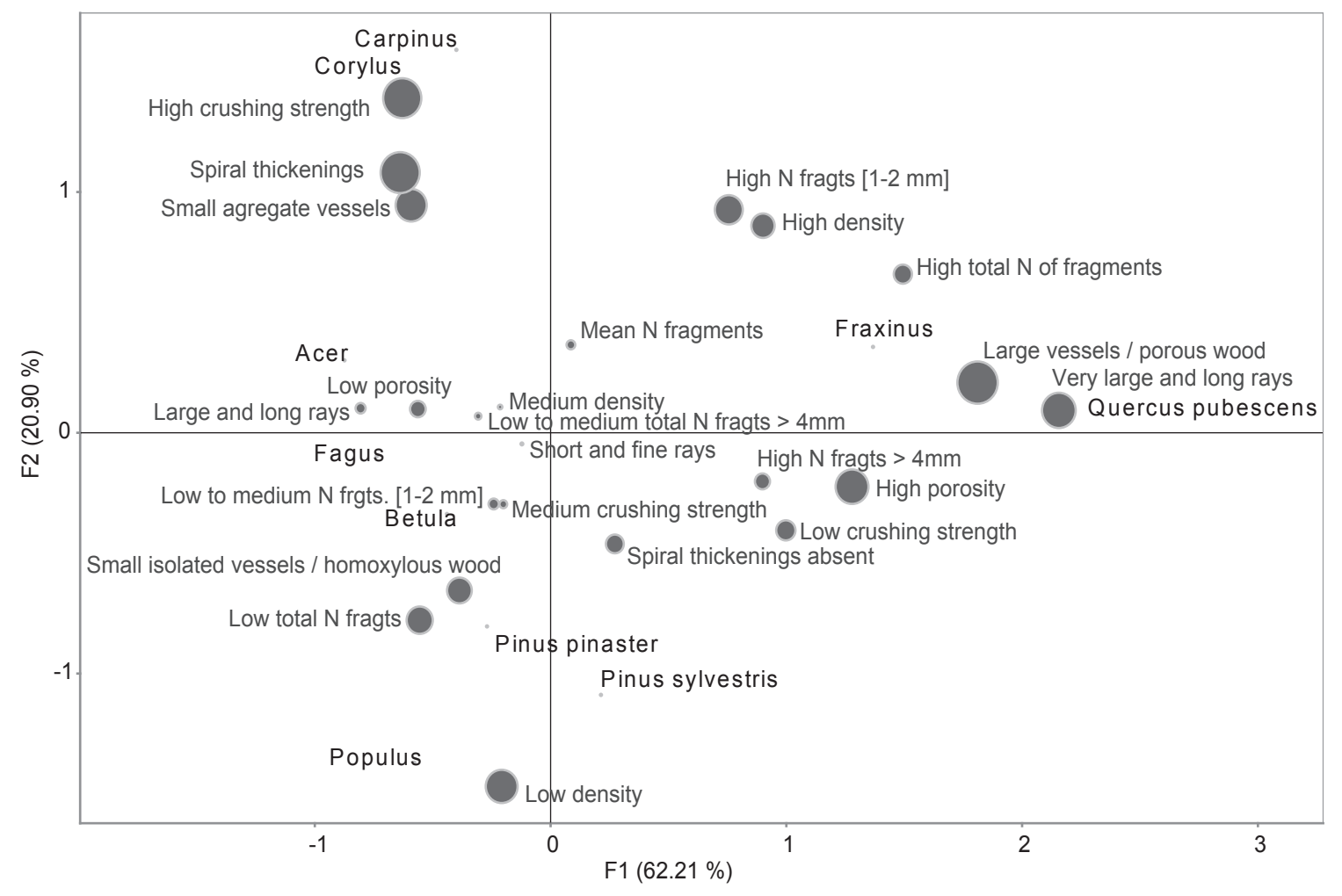

Fig. 9. Multiple Correspondence Analysis (symmetric graph): mechanical properties/ wood anatomy.

bias interpretation. However, crushing strength depends on the formation temperature of charcoal and has no impact on the quantity of fragments produced after the rupture of the material. This results in a set of extremely variable situations where it is impossible to assess or to measure all the parameters. It is thus important to study and to take account of burial conditions (the nature and intensity of post-depositional processes involved in the deposit formation, rate of burial at the scale of the site, but also intra-site variations), but it is nonetheless impossible to infer the mechanical behaviour of charcoal. However, when interpreting the data, it is imperative to bear in mind that some taxa are more fragile than others.

Conversely, the values obtained for crushing strength appear to be more significant. Charcoal tolerates relatively high pressure before fragmentation, oscillating between 8 and $19.4 \mathrm{MPa}$, with an average of 13.7 MPa. Mechanically, charcoal is considered to be fragile. In comparison, the crushing strength of common conifers (uncharred) is between 18 and $30 \mathrm{MPa}$, that of ordinary concrete is between 16 and $40 \mathrm{MPa}$ and that of steel between 235 and $350 \mathrm{MPa}$ (Ashby, 2005). Yet most post-depositional processes do not generate very strong pressure. Cattle exert greater static pressure (160-192 kPa) on soil than sheep ( $83 \mathrm{kPa}$ ), although this pressure is at least doubled when animals are walking (Drewry, 2006), which represents less than 0.4 MPa. The value for human beings cannot be much higher. The maximum pressure measured during freeze propagation experiments in a limestone notch is about $6 \mathrm{MPa}$ (Bost, 2008).

Thus, the intense fragmentation of charcoal (extending at times to the disappearance of the macroscopic fraction), characteristic of some Pleistocene sites (Théry-Parisot, 2001; ThéryParisot et al., 2010a; Beresford-Jones et al., 2010, Marquer et al., 2012) does not seem to result from single, short-term processes. However, classic processes, such as freeze-thaw action or trampling occurring repeatedly during the course of a phase of low (or no) sedimentation, could doubtlessly generate progressive charcoal weakening, leading to extreme fragmentation. Under natural conditions, the repetition of these processes induces progressive mechanical fatigue of the material (which is not measured in our experiment), thereby increasing charcoal damage. Finally, it is important to distinguish post-depositional processes from fuel management. The disappearance of the coarse fraction due to burial conditions sometimes leads to the misinterpretation of charcoal scarcity, suggesting that other fuels, such as bones or dung, were used. Further investigations based on the study of very thin coarse fractions combined with geoarchaeological studies, are required, so that more reliable interpretations can be proposed. (Fernández-Jalvo et al., 2010; Marquer et al., 2010, 2012; Miller et al., 2010; Scott and Damblon, 2010).

Naturally, these observations must be moderated, notably because of the way the samples are made, which is quite far removed from the archaeological reality. Complementary analyses are required, incorporating other criteria, such as the chemical composition of the taxa. Moreover, this paper does not take account of the other stages of fragmentation, namely combustion. Through cross indexing data from research on combustion and postdepositional processes, it will become possible to gain a better understanding of anthracological assemblages.

Based on an innovative experimental approach combining both archaeobotany and biomechanics, these results are fundamental for a comprehensive understanding of archaeology, archaeobotany and palaeoecology. They document the mechanical behaviour of charcoal, a largely unknown domain up until now. They enhance our understanding of charcoal taphonomy by providing added resolution and improving the accuracy of charcoal analysis. 


\section{References}

Ascough, P.L., Bird, M.I., Scott, A.C., Collinson, M.E., Cohen-Ofri, I., Snape, C.E., Le Manquais, K., 2010. Charcoal reflectance measurements: implications for structural characterization and assessment of diagenetic alteration. J. Archaeol. Sci. 37 (7), 1590-1599.

Ascough, P.L., Bird, M.I., Francis, S.M., Lebl, T., 2011a. Alkali extraction of archaeological and geological charcoal: evidence for diagenetic degradation and formation of humic acids. J. Archaeol. Sci. 38 (1), 69-78.

Ascough, P.L., Bird, M.I., Francis, S.M., Thornton, B., Midwood, A.J., Scott, A.C., Apperley, D., 2011b. Variability in oxidative degradation of charcoal: influence of production conditions and environmental exposure. Geochim. Cosmochim. Acta 75 (9), 2361-2378.

Ashby, M.F., 2005. Material Selection in Mechanical Design, third ed. U.K. Butterworth-Heinemann, Oxford, p. 624.

Badal-Garcia, E., 1990. Méthode de prélèvement et paléoécologie du Néolithique d'après les charbons de bois de "La Cova de les Cendres" (Alicante, Espagne). In: Hackens, T., Munaut, A.V., Till, C. (Eds.), Wood and Archaeology, Bois et archéologie, First European Conference, Louvain-la-Neuve, October 2nd-3rd 1987, Pact, 22, pp. 231-243.

Badal-Garcia, E., 1992. L'anthracologie préhistorique: à propos de certains problèmes méthodologiques. In: Vernet, J.L. (Ed.), Les charbons de bois les anciens écosystèmes et le rôle de l'Homme. Bull. Soc. Bot. France 139, 167-189.

Belcher, C.M., Collinson, M.E., Scott, A.C., 2005. Constraints on the thermal energy released from the Chicxulub impactor: new evidence from multi-method charcoal analysis. J. Geol. Soc. London 162, 591-602.

Beresford-Jones, D.G., Johnson, K., Pullen, A.G., Pryor, A.J.E., Svobod, J., Jones, M.K., 2010. Burning wood or burning bone? A reconsideration of flotation evidence from Upper Palaeolithic (Gravettian) sites in the Moravian Corridor. J. Archaeol. Sci. 37 (11), 2799-2811.

Blackford, J.J., 2000. Charcoal fragments in surface samples following a fire and the implications for interpretation of subfossil charcoal data. Palaeogeogr. Palaeoclimatol. Palaeoecol. 164 (1-4), 33-42.

Borrega, M., Kärenlampi, P.P., 2008. Mechanical behavior of heat-treated spruce spruce (Picea abies) wood at constant moisture content and ambient humidity. Holz Roh Werkst 66, 63-69.

Bost, M., 2008. Altération par le gel des massifs rocheux: Etude expérimentale et modélisation des mécanismes de génération des contraintes dans les fissures. Thèse de doctorat, Paristech, p. 281.

Braadbaart, F., Poole, I., 2008. Morphological, chemical and physical changes during charcoalification of wood and its relevance to archaeological contexts. J. Archaeol. Sci. 35 (9), 2434-2445.

Braadbaart, F., Poole, I., Van Brussel, A.A., 2009. Preservation potential of charcoal in alkaline environments: an experimental approach and implications for the archaeological record. J. Archaeol. Sci. 36 (8), 1672-1679.

Braadbaart, F., Poole, I., Huisman, Hans D.J., van Os, B., 2012. Fuel, Fire and Heat: an experimental approach to highlight the potential of studying ash and char remains from archaeological contexts. J. Archaeol. Sci. 39 (4), 836-847.

Byrne, C.E., Nagle, D.C., 1997. Carbonization of wood for advanced materials applications. Carbon 35, 259-266.

Carcaillet, C., 2001. Soil particles reworking evidences by AMS 14C dating of charcoal. Comp. Rend. Acad. Sci. Paris Sér. Sci. Terre Planèt. 332, 21-28.

Carcaillet, C., Talon, B., 1996. Stratigraphie et datations de charbons de bois dans les Alpes: quelques aspects taphonomiques. Géogr. Phys. Quatern. 50, 233-244.

Chabal, L., 1988. Pourquoi et comment prélever les charbons de bois pour la période antique: les méthodes utilisées sur le site de Lattes (Hérault), Lattara, 1, A.R.A.L.O. Ed., Lattes, 187-222.

Chabal, L., 1990. L'étude paléo-écologique de sites protohistoriques à partir des charbons de bois: la question de l'unité de mesure. Dénombrement de fragments ou pesées? In: Hackens, T., Munaut, A.V., Till, Cl (Eds.), Wood and Archaeology. Bois et archéologie. First European Conference, Louvain-la-Neuve, October 2nd-3rd 1987, Belgique, PACT, 22, pp. 189-205.

Chabal, L., 1991. L'Homme et l'évolution de la végétation méditerranéenne, des âges des métaux à la période romaine: recherches anthracologiques théoriques, appliquées principalement à des sites du Bas-Languedoc. Thèse de Doctorat. Université de Montpellier II, p. 435.

Chabal, L., 1997. Forêts et sociétés en Languedoc (Néolithique final, Antiquité tardive. L'anthracologie, méthode et paléoécologie. DAF 63. Éditions de la Maison des Sciences de l'Homme, Paris, $192 \mathrm{p}$.

Cohen-Ofri, I., Weiner, L., Boaretto, E., Mintz, G., Weiner, S., 2006. Modern and fossil charcoal: aspects of structure and diagenesis. J. Archaeol. Sci. 33 (3), 428-439.

Costamagno, S., Théry-parisot, I., Kuntz, D., Bon, F., Mensan, R., 2010. Impact taphonomique d'une combustion prolongée sur des ossements utilisés comme combustible. In: Théry-Parisot, I., Chabal, L., Costamagno, S. (Eds.), The Taphonomy of Burned Organic Residues and Combustion Features in Archaeological Contexts. Proceedings of the round table, Valbonne, May 27-29, 2008. Palethnologie 2, 173-187.

Drewry, J.J., 2006. Natural recovery of soil physical properties from treading damage of pastoral soils in New Zealand and Australia: a review. Agric. Ecosyst. Environ. $114(2-4), 159-169$.

Ducom, A., 2010. Comportement de charbons de bois face à la compression et applications en archéologie. Unpublished report. École Polytechnique de Paris, p. 23.

Fengel, D., Wegener, G., 1989. Wood Chemistry, ultrastructure, reactions. Walter de Gruyter 33, 333-335.
Fernández-Jalvo, Y., Scott, L., Andrews, P., 2010. Taphonomy in palaeoecological interpretations. Q. Sci. Rev. 30 (11-12), 1296-1302.

Forest Products Laboratory, 2010. Wood Handbook: Wood as an Engineering Material. USDA, Madison, p. 508.

Gibson, L.J., Ashby, M.F., 1999. Cellular Solids: Structure \& Properties. Cambridge University Press, p. 510

Goldberg, P., Macphail, R.I., 2013. Practical and Theoretical Geoarchaeology. Published Online: 3 MAY 2013. Blackwell Publishing Ltd. http://dx.doi.org/10.1002/ 9781118688182

Gündüz, G., Korkut, S., Korkut, D.S., 2008. The effects of heat treatment on physical and technological properties and surface roughness of Camiyanı Black Pine (Pinus nigra Arn. subsp. pallasiana var. pallasiana) wood. Bioresour. Technol. 99, 2275-2280.

Hillis, W.E., 1984. High temperature and chemical effects on wood stability. Wood Sci. Technol. 18, 281-293.

Kocaefe, D., Poncsak, S., Tang, J., Bouazara, M., 2010. Effect of heat treatment on the mechanical properties of North American jack pine: thermogravimetric study. J. Mater. Sci. 45 (3), 681-687.

Korkut, S., Akgül, M., Dündar, T., 2008. The effects of heat treatment on some technological properties of Scots pine (P. sylvestris, P. sylvestris L.) wood. Bioresour. Technol. 99, 1861-1868.

Korkut, S., Hiziroglu, S., 2009. Effect of heat treatment on mechanical properties of hazelnut wood (Corylus colurna L.). Mater. Design 30, 1853-1858.

Lancelotti, C., Madella, M., Ajithprasad, P., Petrie, C., 2010. Temperature, compression and fragmentation: an experimental analysis to assess the impact of taphonomic processes on charcoal preservation. Archaeol. Anthropol. Sci. 2, 307-320.

Lingens, A., Windeisen, E., Wegener, G., 2005. Investigating the combustion behavior of various wood species via their fire gases. Wood Sci. Technol. 39 (1), 49-60.

Loreau, P., 1994. Du bois au charbon de bois: approche expérimentale de la combustion. Unpublished Master 2. Université de Montpellier II, p. 64.

Majano-Majano, A., Hughes, M., Fernandez-Cabo, J.L., 2012. The fracture toughness and properties of thermally modified beech and ash at different moisture contents. Wood Sci. Technol. 46, 5-21.

Marquer, L., Otto, T., Nespoulet, R., Chiotti, L., 2010. A new approach to study the fuel used in hearths by hunter-gatherers at the Upper Palaeolithic site of Abri Pataud (Dordogne, France). J. Archaeol. Sci. 37 (11), 2735-2746.

Marquer, L., Lebretona, V., Otto, T., Valladas, H., Haesaerts, P., Messager, E., Nuzhnyi, D., Péan, S., 2012. Charcoal scarcity in Epigravettian settlements with mammoth bone dwellings: the taphonomic evidence from Mezhyrich (Ukraine). J. Archaeol. Sci. 39 (1), 109-120.

Mburu, F., Dumarçay, S., Bocquet, J.F., Pétrissans, M., Gérardin, P., 2008. Effect of chemical modifications caused by heat treatment on mechanical properties of Grevillea robusta wood. Polymer Degrad. Stab. 93, 401-405.

Miller, C.E., Conard, N.J., Goldberg, P., Berna, F., 2010. Dumping, sweeping and trampling: experimental micromorphological analysis of anthropogenically modified combustion features. In: Théry-Parisot, I., Chabal, L., Costamagno, S. (Eds.), The Taphonomy of Burned Organic Residues and Combustion Features in Archaeological Contexts. Proceedings of the Round Table, Valbonne, May 2729, 2008. Palethnologie 2, 25-37.

Nichols, G., Cripps, J.A., Collinson, M.E., Scott, A.C., 2000. Experiments in waterlogging and sedimentology of charcoal: results and implications. Palaeogeogr. Palaeoclimatol. Palaeoecol. 164 (1-4), 43-56.

Poletto, M., Zattera, A.J., Forte, M.C., Santana, R., 2012. Thermal decomposition of wood: influence of wood components and cellulose crystallite size. Bioresour. Technol. 109, 148-153.

Prior, J., Gasson, P., 1993. Anatomical changes on charring six African hardwoods. IAWA J. 14, 77-86.

Rebollo, N.-R., Cohen-Ofri, I., Popovitz-Biro, R., Bar-Yosef, O., Meignen, L., Goldberg, P., Weiner, S., Boaretto, E., 2008. Structural characterization of charcoal exposed to high and low ph: implications for $14 \mathrm{c}$ sample preparation and charcoal preservation. Radiocarbon 50 (2), 289-307.

Rossen, J., Olson, J., 1985. The controlled carbonisation and archaeological analysis of SE U.S. wood charcoals. J. Field Archaeol. 12, 445-456.

Rousset, P., Turner, I., Donnot, A., Perré, P., 2006. Choix d'un modèle de pyrolyse ménagée du bois à l'échelle de la microparticule en vue de la modélisation macroscopique. Ann. Forest Sci. 63, 213-229.

Salisbury, K.J., Jane, F.W., 1940. Charcoals from Maiden Castle and their significance in relation to the vegetation and climatic conditions in prehistoric times. J. Ecol. $28,310-325$.

Santa, S., 1961. Essai de reconstitution de paysages végétaux Quaternaires d'Afrique de Nord. Libyca 6-7, 37-77.

Schiegl, S., Goldberg, P., Bar-Yosef, O., Weiner, S., 1996. Ash deposits in Hayonim and Kebara caves, Israel: macroscopic, microscopic and mineralogical observations, and their archaeological implications. J. Archaeol. Sci. 23 (5), $763-781$.

Scott, A., 2010. Charcoal recognition, taphonomy and uses in palaeoenvironmental analysis. Palaeogeogr. Palaeoclimatol. Palaeoecol. 291 (1-2), 11-39.

Scott, A.C., Jones, T.P., 1991. Microscopical observations of Recent and fossil charcoal. Microscopy Anal. 24, 13-15.

Scott, A.C., Cripps, J.A., Collinson, M.E., Nichols, G.J., 2000. The taphonomy of charcoal following a recent heathland fire and some implications for the interpretation of fossil charcoal deposits. Palaeogeogr. Palaeoclimatol. Palaeoecol. $164(1-4), 1-31$. 
Scott, A., Damblon, F., 2010. Charcoal: taphonomy and significance in geology, botany and archaeology. Palaeogeogr. Palaeoclimatol. Palaeoecol. 291 (1-2), $1-10$.

Smart, T.L., Hoffman, E.S., 1988. Environmental interpretation of archaeological charcoal. In: Hastorf, C.A., Popper, V.S. (Eds.), Current Paleoethnobotany. University of Chicago Press, Chicago and London, pp. 165-205.

Théry-Parisot, I., 1998. Économie des combustibles et paléoécologie en contexte glaciaire et périglaciaire, Paléolithique moyen et supérieur du sud de la France. Anthracologie, Expérimentation, Taphonomie. Thèse de doctorat. Université de Paris I, Paris, p. 500

Théry-Parisot, I., 2001. Économie des combustibles au Paléolithique, Anthracologie, Expérimentation, Taphonomie. Dossier de Documentation Archéologique, 20. CNRS Editions, 195 p.

Théry-Parisot, I. 2013. Gestion des ressources combustibles et environnements des sociétés préhistoriques du sud de la France. Apport de l'expérimentation à la compréhension des pratiques et des dépôts. Mémoire d'habilitation à Diriger des Recherches, Université de Nice Sophia Antipolis, 187p.

Théry-Parisot, I., Chabal, L., Chrzavzez, J., 2010a. Anthracology and taphonomy, from wood gathering to charcoal analysis. A review of the taphonomic processes modifying charcoal assemblages. Palaeogeogr. Palaeoclimatol. Palaeoecol. 29 $(1-2), 142-153$
Théry-Parisot, I., Chabal, L., Costamagno, S., 2010b. The taphonomy of burned organic residues and combustion features in archaeological contexts. Proceedings of the round table, Valbonne, May 27-29, 2008. Palethnologie 2, 223.

Théry-Parisot, I., Chabal, L., 2010c. From wood to wood charcoal: an experimental approach to combustion/Du bois au charbons de bois, approche expérimentale de la combustion. In: Théry-Parisot, I., Chabal, L., Costamagno, S. (Eds.), The Taphonomy of Burned Organic Residues and Combustion Features in Archaeological Contexts. Proceedings of the Round Table, Valbonne, May 27-29, 2008 Palethnologie 2, 81-93.

Thiébault, S., 1980. Étude critique des aires de combustion en France, Mémoire de Maîtrise. Université de Paris I, Paris, p. 246.

Thinon, M., 1992. Analyse pédoanthracologique: aspects méthodologiques et applications. Thèse de doctorat. Université Aix-Marseille, p. 272.

Vaughan, A., Nichols, G.J., 1995. Controls on the deposition of charcoal: implications for sedimentary accumulations of fusain. J. Sediment. Res. 65, 129-135.

Vernet, J.-L., 1973. Étude sur l'histoire de la végétation du sud-est de la France au Quaternaire d'après les charbons de bois principalement. Paléobiol. Continent. 4 (1), 1-90.

Yildiz, S., Gezer, E.D., Yildiz, U.C., 2006. Mechanical and chemical behavior of spruce wood modified by heat. Build. Environ. 41, 762-766. 